\begin{tabular}{|c|c|c|c|c|c|c|}
\hline \multirow{4}{*}{ Impact Factor: } & ISRA (India) & $=3.117$ & SIS (USA) & $=0.912$ & ICV (Poland) & $=6.630$ \\
\hline & ISI (Dubai, UAE & $=0.829$ & РИНЦ (Russia) & $=0.156$ & PIF (India) & $=1.940$ \\
\hline & GIF (Australia) & $=0.564$ & ESJI (KZ) & $=8.716$ & IBI (India) & $=4.260$ \\
\hline & JIF & $=1.500$ & SJIF (Morocco) & $=5.667$ & OAJI (USA) & $=0.350$ \\
\hline
\end{tabular}

\section{SOI: $\underline{1.1 / \text { TAS }}$ DOI: $10.15863 /$ TAS \\ International Scientific Journal Theoretical \& Applied Science}

\author{
p-ISSN: 2308-4944 (print) e-ISSN: 2409-0085 (online) \\ Year: $2019 \quad$ Issue: $07 \quad$ Volume: 75
}

Published: 29.07.2019

http://T-Science.org
QR - Issue
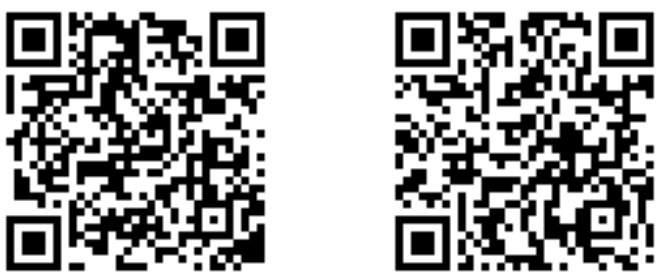

Alina A. Karahanova Kyrgyz National University name of Zhusup Balasagyn 3rd year graduate student of the Department of civil law

\title{
ORDER OF ADOPTION OF CHILDREN BY FOREIGN CITIZENS ON THE TERRITORY OF THE KYRGYZ REPUBLIC
}

Abstract: The article is devoted to the legal regulation of adoption of Kyrgyz children by foreign citizens. The article describes in detail the process and procedure of adoption of Kyrgyz children by foreign citizens. A positive and negative assessment of the national legislation on the regulation of the issue of adoption of children by foreign citizens is given.

Key words: citizenship, foreigner, legislation.

Language: Russian

Citation: Karahanova, A. A. (2019). Order of adoption of children by foreign citizens on the territory of the Kyrgyz republic. ISJ Theoretical \& Applied Science, 07 (75), 340-343.

Soi: http://s-o-i.org/1.1/TAS-07-75-54 Doi: crossef https://dx.doi.org/10.15863/TAS.2019.07.75.54

Classifiers: Jurisprudence.

\section{ПОРЯДОК УСЫНОВЛЕНИЯ (УДОЧЕРЕНИЯ) ДЕТЕЙ ИНОСТРАННЫМИ ГРАЖДАНАМИ НА ТЕРРИТОРИИ КЫРГЫЗСКОЙ РЕСПУБЛИКИ}

Аннотация: Статья посвящена вопросам правового регулирования усыновления иностранными гражданами кыргызских детей. В статье подробно излагается процесс и порядок усыновления иностранными гражданами кыргызских детей. Дается положительная и отрицательная оценка национальному законодательству по регулированию вопроса об усыновлении (удочерении) детей иностранными гражданами.

Ключевые слова: усыновление, дети, иностранный гражданин.

\section{Введение}

Национальное законодательство Кыргызской Республики называет усыновление в качестве приоритетной формы устройства детей, оставшихся без попечения родителей, по отношению к опеке и попечительству, приемной семье $[1$, с. 16 , с. 18]. Увеличение масштабов усыновления иностранными гражданами кыргызских детей, вывоз усыновленных детей из страны поставили на повестку дня решение проблем, связанных с более тщательной правовой регламентацией усыновления детей иностранцами. Такая задача возникла и в Кыргызской Республике, куда обращаются граждане многих государств с просьбой о передаче им детей на усыновление. А причин для этого достаточно много: рост числа детей, оставшихся без попечения родителей на территории Кыргызской Республики, среди которых немало инвалидов; социальноэкономические потрясения, не позволяющие должным образом обеспечить нормальное существование этих детей, и т. д. Так, в Кыргызстане есть 145 детских учреждений, в которых находятся 12 тыс. детей [2]. С другой стороны, все больше становится иностранных граждан, которые не могут иметь детей и не имеют возможности усыновить ребенка в своей стране. Одна из причин - более жесткие, чем в Кыргызстане, условия усыновления в собственной стране. Например, в Нидерландах усыновление разрешается только женатым парам с брачным стажем не менее пяти лет. В Испании лицо, усыновляющее ребенка, должно быть не моложе 25 лет. Кроме того, само число детей, оставшихся без попечения родителей, в странах, которые 


\begin{tabular}{llllll} 
& ISRA (India) $=\mathbf{3 . 1 1 7}$ & SIS (USA) $=\mathbf{0 . 9 1 2}$ & ICV (Poland) & $\mathbf{= 6 . 6 3 0}$ \\
Impact Factor: & ISI (Dubai, UAE) $=\mathbf{0 . 8 2 9}$ & PUHЦ (Russia) $=\mathbf{0 . 1 5 6}$ & PIF (India) & $=\mathbf{1 . 9 4 0}$ \\
& GIF (Australia) $=\mathbf{0 . 5 6 4}$ & ESJI (KZ) & $\mathbf{8 . 7 1 6}$ & IBI (India) & $=\mathbf{4 . 2 6 0}$ \\
& JIF & $\mathbf{1 . 5 0 0}$ & SJIF (Morocco) $=\mathbf{5 . 6 6 7}$ & OAJI (USA) & $\mathbf{0 . 3 5 0}$ \\
\hline
\end{tabular}

принято называть развитыми, значительно меньше [3]. Усыновление - это сложный юридический акт. В нем находят отражение как воля лиц, выразивших желание усыновить ребенка, родителей, давших согласие на усыновление своего ребенка, самого ребенка, достигшего 10-летнего возраста, и других лиц, установленных законом, так и воля государства, выраженная в решении суда. Таким образом, государственная воля оказывает определенное влияние на возникновение порождаемых усыновлением отношений. Государство посредством судебных органов власти непосредственно выражает свою волю и участвует в формировании самого акта усыновления. Без прямо выраженной его воли на усыновление соответствующие этому акту отношения возникнуть не могут. На этом основании можно заключить, что решение суда входит в содержание акта усыновления в качестве его неотъемлемой части, а не просто действия, которыми регулируется усыновление [4, с. 26, с. 32]. Усыновление детей в Кыргызской Республике регулируется международными нормативноправовыми актами и национальным законодательством. Систему нормативноправовых актов Кыргызской Республике составляют Семейный кодекс Кыргызской Республики от 30 августа 2003 года № 201, Гражданский процессуальный кодекс Кыргызской Республики от 25 января 2017 года № 14, Кодекс Кыргызской Республики «О детях» от 10 июля 2012 года № 100, Закон Кыргызской Республики «О гражданстве Кыргызской Республики» от 21 мая 2007 года № 70, Постановление Правительства Кыргызской Республики от 6 декабря 2013 года № 660 «О порядке аккредитации иностранных организаций по осуществлению на территории Кыргызской Республики межгосударственного усыновления (удочерения) детей - граждан Кыргызской Республики».

Международное усыновление - это усыновление, в котором есть иностранный элемент, в данном случае он выражается в том, что усыновленный и усыновитель имеют разное гражданство либо усыновление происходит на территории иностранного государства $[5$, с. 17 , с. 20]. Основные принципы межгосударственного усыновления закреплены в международных документах. Прежде всего, в Конвенции о правах ребенка от 20 ноября 1989 года [6]. Среди принципов выделяют, во-первых, признание его в качестве альтернативного способа ухода за детьми, лишенными семейного окружения, допустимого лишь тогда, когда «обеспечение какого-либо подходящего ухода в стране происхождения ребенка является невозможным».
Это связано с тем, что усыновление ребенка усыновителями страны происхождения позволяет компетентным органам государства в наилучшей степени контролировать соблюдение законных интересов усыновленного, а также ограничивать и пресекать преступные посягательства на интересы ребенка со стороны усыновителей и иных лиц.

Во-вторых, отнесение решения вопроса об усыновлении к ведению компетентных органов государства.

В-третьих, необходимость того, чтобы при усыновлении в другой стране относительно ребенка применялись те же гарантии и нормы, которые используются при внутригосударственном усыновлении.

И, наконец, в-четвертых, недопущение того, чтобы устройство ребенка приводило к получению неоправданных финансовых и иных выгод связанными с усыновлением лицами. Правовое регулирование в области усыновления осуществляется также с помощью международной конвенции «О защите детей и сотрудничестве в отношении иностранного усыновления», принятой в Гааге 29 мая 1993 г. [7].

Положение «О порядке аккредитации иностранных организаций по осуществлению на территории Кыргызской Республики межгосударственного усыновления (удочерения) детей - граждан Кыргызской Республики» [8] восприняв основные принципы международного права в области усыновления, содержит принципиальную норму, ограничивающую усыновление детей иностранными гражданами.

В соответствии с п. 29 усыновление детей граждан Кыргызской Республики иностранными гражданами допускается только в тех случаях, если не представляется возможным передать этих детей на воспитание родственникам независимо от гражданства и места жительства либо гражданам Кыргызской Республики.

Тем самым международное усыновление признается также и кыргызским законодателем в качестве альтернативного способа ухода за ребенком: приоритетным является его усыновление гражданами Кыргызской Республики [4].

Усыновление иностранными гражданами кыргызских детей производится по праву страны гражданства усыновителей. Тем не менее для обеспечения интересов кыргызских детей необходимо соблюдение требований кыргызского законодательства. Вместе с тем даже безупречные c точки зрения юридической техники и содержания нормы права на практике, к сожалению, применяются в противоречии с приоритетом устройства кыргызских детей в семьи граждан Кыргызской Республики. Процедура международного усыновления требует 


\begin{tabular}{llllll} 
& ISRA (India) $=\mathbf{3 . 1 1 7}$ & SIS (USA) & $=\mathbf{0 . 9 1 2}$ & ICV (Poland) & $=\mathbf{6 . 6 3 0}$ \\
Impact Factor: & ISI (Dubai, UAE) $=\mathbf{0 . 8 2 9}$ & PUHL (Russia) $=\mathbf{0 . 1 5 6}$ & PIF (India) & $=\mathbf{1 . 9 4 0}$ \\
& GIF (Australia) $=\mathbf{0 . 5 6 4}$ & ESJI (KZ) & $=\mathbf{8 . 7 1 6}$ & IBI (India) & $=\mathbf{4 . 2 6 0}$ \\
& JIF & $\mathbf{1 . 5 0 0}$ & SJIF (Morocco) $=\mathbf{5 . 6 6 7}$ & OAJI (USA) & $\mathbf{0 . 3 5 0}$ \\
\hline
\end{tabular}

повышенного внимания, поскольку усыновляемые дети передаются на воспитание в семьи иностранных граждан, проживающих, как правило, за пределами Кыргызской Республики. Это обусловливает необходимость формирования особого порядка международного усыновления и системы мер контроля за усыновленными детьми в целях защиты их прав и законных интересов на территории иностранного государства. Кроме того, сложность правового регулирования данного вида правоотношений заключается в том, что участники семейных отношений, осложненных иностранным элементом, являются гражданами двух, а то и более иностранных государств. На первый план выходит проблема выбора законодательства, подлежащего применению в каждом конкретном случае международного усыновления. Также нельзя не упомянуть о столкновении правовых систем различных государств, дифференциации источников правового регулирования [9, с. 68, с. 71]. Усыновление иностранными гражданами ребенка допускается только в отношении несовершеннолетних детей и только в их интересах с обязательным учетом этнического происхождения, религиозной и культурной принадлежности, родного языка, возможности обеспечения преемственности в воспитании и образовании детей. Судебный порядок рассмотрения дел об усыновлении регламентируется Гражданским процессуальным кодексом Кыргызской Республики и призван обеспечить дополнительные гарантии соблюдения законности, прав и интересов детей при усыновлении. В соответствии с действующим законодательством при рассмотрении судом дел об усыновлении обязательно участие органа опеки и попечительства, а также прокурора. Между тем зачастую у суда нет реальных возможностей убедиться в действительности представленных в судебное заседание документов.

Не смотря на то, что перечень представляемых документов является достаточно широким:

1) заявление о своем желании усыновить ребенка с указанием пола, возраста и иных сведений о ребенке, которого хотели бы усыновить;

2) копию паспорта, копию свидетельства о браке (если усыновляет супружеская пара);

3) справку с места работы о занимаемой должности и заработной плате, либо копия декларации о доходах или иной документ о доходах;

4) документ, подтверждающий право собственности на жилое помещение или право пользования жилым помещением;
5) документ, подтверждающий отсутствие судимости и фактов жестокого обращения (насилия) в отношении детей;

6) разрешение компетентного органа соответствующего государства на въезд усыновляемого ребенка в принимающее государство и его постоянное жительство на территории этого государства;

7) медицинское заключение о состоянии здоровья, в том числе об отсутствии наркотической (токсической), алкогольной зависимости и психического расстройства;

8) копию сертификата, подтверждающего прохождение обучения по подготовке приемных родителей;

9) копию соглашения между потенциальными усыновителями и аккредитованной иностранной организацией о предоставлении услуг по вопросу межгосударственного усыновления;

10) заключение об исследовании жилищносоциальных условий потенциальных усыновителей, составленное социальным работником;

11) письменное обязательство потенциальных усыновителей с указанием:

- о постановке на консульский учет усыновляемого ребенка в дипломатическом представительстве (посольстве) или консульском учреждении Кыргызской Республики, аккредитованном в государстве проживания усыновителей, при въезде его в иностранное государство;

- $о$ предоставлении возможности обследования условий жизни и воспитания усыновляемого ребенка работниками дипломатического представительства (посольства) или консульского учреждения Кыргызской Республики;

- об обучении усыновленного ребенка в образовательном учреждении и постановке на медицинский учет по месту постоянного проживания, усыновителей;

- о сохранении гражданства Кыргызской Республики за усыновленным ребенком и его нахождении на учете в дипломатическом представительстве (посольстве) или консульском учреждении Кыргызской Республики до достижения им возраста 18 лет;

- о предоставлении отчетов об условиях жизни и воспитания детей в семьях через аккредитованную иностранную организацию, а в случае ликвидации (банкротства) аккредитованной иностранной организации через другие иностранные организации [10].

Как показала практика, получить нужные документы иностранным усыновителям не составляет особого труда. При оформлении 


\begin{tabular}{|c|c|c|c|c|c|c|}
\hline \multirow{4}{*}{ Impact Factor: } & ISRA (India) & $=3.117$ & SIS (USA) & $=0.912$ & ICV (Poland) & $=6.630$ \\
\hline & ISI (Dubai, UAE & $=0.829$ & РИНЦ (Russia) & $=0.156$ & PIF (India) & $=1.940$ \\
\hline & GIF (Australia) & $=0.564$ & ESJI (KZ) & $=8.716$ & IBI (India) & $=4.260$ \\
\hline & JIF & $=1.500$ & SJIF (Morocco) & $=5.667$ & OAJI (USA) & $=0.350$ \\
\hline
\end{tabular}

многих справок применяются коррумпированные схемы за определенное вознаграждение. Поэтому сегодня со стороны государства существует необходимость в построении хороших условий и льгот для кыргызских усыновителей.

\section{References:}

1. Arutyunova, E. V. (2010). The concept and legal nature of adoption. Family and housing law, № 2, pp. 16-18.

2. (n.d.). National Statistical Committee of the Kyrgyz Republic.

3. Grishaev, S. P. (2009). Family legal relations with the participation of foreign citizens. Family legal relations with the participation of foreign citizens. Access from the legal system "ConsultantPlus".

4. Kosova, O. N. (2001). Features of international adoption. Legitimacy, № 1, pp. 26-32.

5. Parshukova, K. Y. (2008). General characteristics of relations generated by adoption, and their legal nature. Family and housing law, № 2, pp. 17-20.

6. (1989). The UN Convention on the Rights of the Child on November 20, 1989.

7. (1993). Convention on the Protection of Children and Cooperation in Respect of Foreign
Adoption, adopted at the Hague on May 29, 1993.

8. (2013). Decree of the Government of the Kyrgyz Republic of December 6, 2013 No. 660 "On the procedure for accreditation of foreign organizations for the implementation in the territory of the Kyrgyz Republic of intergovernmental adoption (adoption) of children - citizens of the Kyrgyz Republic".

9. Tsvetkova, O. A. (2008). The ban on mediation in international adoption. Law and Education, № 3 , pp. 68-71.

10. (2013). Decree of the Government of the Kyrgyz Republic of December 6, 2013 No. 660 "On the procedure for accreditation of foreign organizations for the implementation in the territory of the Kyrgyz Republic of intergovernmental adoption (adoption) of children - citizens of the Kyrgyz Republic". 